Fourth International Conference on Sustainable Construction Materials and Technologies http://www.claisse.info/Proceedings.htm

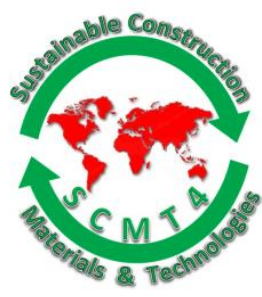

SCMT4

Las Vegas, USA, August 7-11, 2016

\title{
A Case Study of Strengthening of Distressed Prestressed Concrete Box-Girder Bridge
}

\author{
Rajeev Goel $^{1 \mathrm{a}}$, S.K. Sharma ${ }^{1 \mathrm{~b}}$, J.K. Goyal ${ }^{1 \mathrm{c}}$, Lakshmy Parmeswaran ${ }^{1 \mathrm{~d}}$, and \\ Rajeev Garg ${ }^{1 \mathrm{e}}$ \\ ${ }^{1}$ CSIR-Central Road Research Institute, Mathura Road, P.O. CRRI, New Delhi-110025, India. \\ ${ }^{1 a}$ Email: <rgoel.crri@nic.in>, ${ }^{1 b}$ Email: <sksharma.crri@nic.in>, ${ }^{1 c}$ Email: <jkgoyal1966@gmail.com>, \\ ${ }^{1 d}$ Email: <lakshmy.crri@nic.in>, ${ }^{1 e}$ Email: <rajeev.crri@nic.in>.
}

\begin{abstract}
Bridges are life line of the nation. Therefore, any distress in the bridges needs to be properly assessed and repaired in time. Before carrying out any repairs/strengthening, exact reasons for the distress in the bridges shall be identified first.
\end{abstract}

This paper gives various techniques for assessment of the condition of the bridges. The paper also presents a case study of four-lane dual independent carriageways prestressed concrete single-cell boxgirder bridge, which is curved in plan. During construction of one of the carriageway of the bridge, distresses were observed near the end diaphragms of one of the span of the bridge while the bridge span was still resting on scaffolding. Non-destructive investigations were done on the distressed span of the bridge which include visual inspection, Schmidt rebound hammer test, ultrasonic pulse velocity test, boroscopy, carbonation test, profometer test etc. Based on the investigation results, the causes for the distresses were identified and a suitable strengthening scheme was suggested which includes repair of spalled concrete, repair of honeycombed areas and prestressing of remaining tendons.

After completing the strengthening of the span as per the suggested scheme and before opening the bridge for the traffic, assessment of the bridge was again carried out to check the efficacy of the strengthening measures. Based on the satisfactory results of this assessment, scaffolding was removed from below. Selfstanding of the bridge span without any scaffolding shows the efficacy of the strengthening scheme. Load test of the bridge was also carried out. Details of all these are given in this paper.

\section{INTRODUCTION}

A grade-separator was to be constructed at Polytechnic crossing in Lucknow city on National Highway24A. The grade separator was on a curve and had two independent carriageways namely 'Inner carriageway' and 'Outer carriageway'. Each carriageway had 4 spans of single cell box-girder shape (consisting of soffit slab, web and deck slab), each of $35.5 \mathrm{~m}$ length and simply supported over a pair of pot bearings on each support. Each box girder was to be prestressed with 18 Nos. of prestressing tendons. Figure 1 shows the location plan of the grade separator. Typical longitudinal section of the distressed span is shown in figure 2 . 


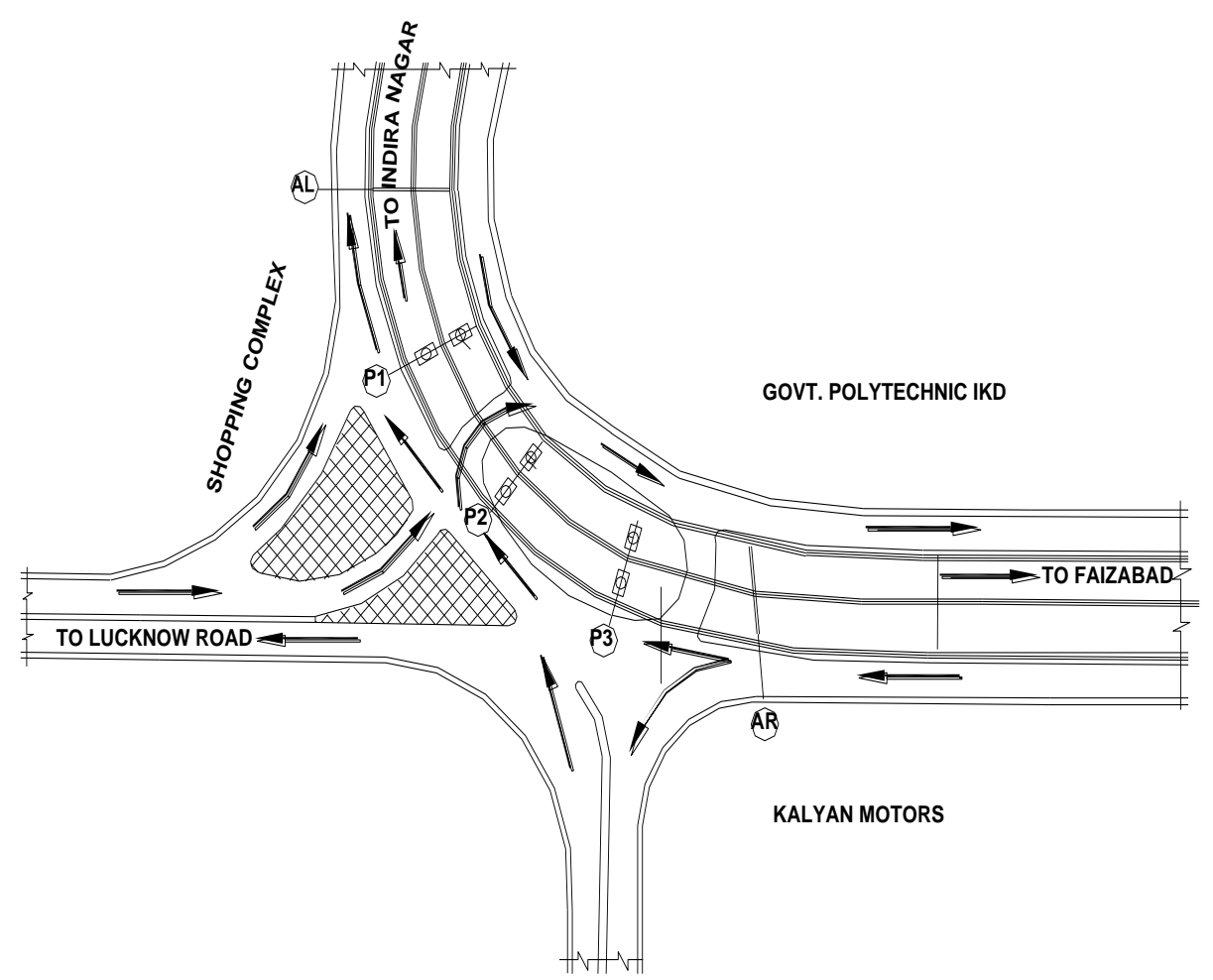

Figure 1. Location Plan of Grade Separator

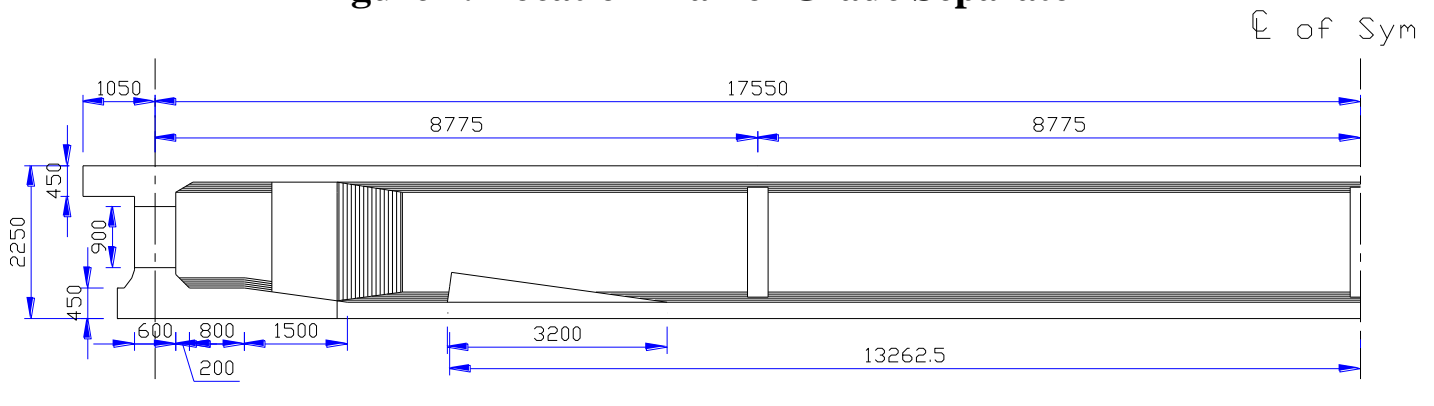

Figure 2. Typical Longitudinal Section of Box-Girder Span

Before the completion of the work, the contract was terminated and the leftover work was awarded to another Contractor. Two spans of Inner carriageway and one span of Outer carriageway were completed by the previous Contractor. The soffit slab and the web portion of the one of the Outer span P2-P3 was cast in-situ by the previous Contractor while, the deck was to be cast by new Contractor. As the box girder was designed for single stage prestressing (i.e. Prestressing only after the casting of soffit slab, web and deck slab), therefore this span could not be prestressed earlier and remained supported on the shuttering for about two years. As soon as the work of prestressing was started by the new Contractor after casting of deck slab of the span P2-P3, end anchorage blocks started caving, one after another. The work was immediately stopped. Detailed inspections/investigations were then conducted on this span. Based on test results and visual inspection, scheme of its rehabilitation was prepared. Post rehabilitation assessment of the bridge was also carried out.

\section{FIELD INVESTIGATIONS}

During field investigations in October 2007, it was noticed that out of 18 numbers of prestressing cables, 5 numbers of prestressing cables (four in soffit slab and one in web) were yet to be stressed in span P2-P3. It was observed that this span was still resting on the staging. Honeycombing, spalling of concrete and 
exposure of steel reinforcement were observed in the soffit slab near the junctions of end-diaphragm walls and inclined web and in the vicinity of bearings (refer figure 3). Application of epoxy mortar and grout nipples in the affected areas was also noticed. Shuttering plates under the entire area of soffit slab except near end-diaphragm walls were still at place. Due to this reason, the concrete of soffit slab behind these shuttering plates could not be inspected.
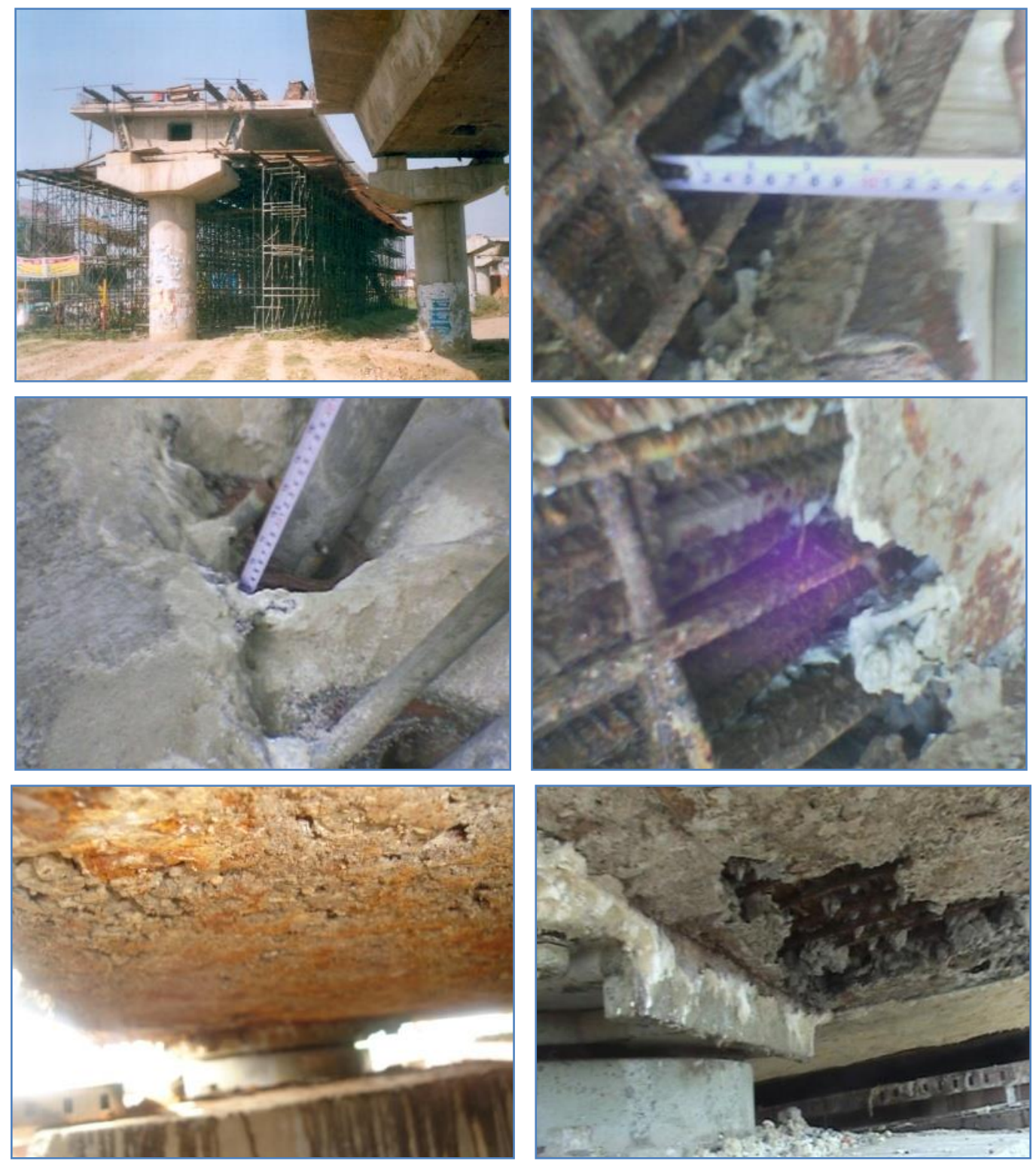

Figure 3. Views of Distressed Span P2-P3 on Outer Carriageway

Schmidt Rebound Hammer test, Ultrasonic Pulse Velocity test, Examination of honeycombing inside the concrete using Boroscope and Covermeter test were carried out to evaluate the quality of in-situ concrete in the vicinity of end diaphragms of span P2-P3. The brief discussion on field observations and investigation is as given below:

- The reinforcement in the vicinity of bearing region was not spaced properly (bars butting each other) which has hindered in pouring of the concrete. The improper bar spacing and use of ungraded 
aggregates had resulted to honeycombing and exposure of reinforcement in the vicinity of bearing, which was on the inner edge of Faizabad end was more than the bearing under the outer web. The same condition was observed on Sitapur end also. It was revealed that the bearing region of inner edge of both the supports had honeycombing. The depth of spalling of concrete in soffit slab was up to the level of second layer main reinforcement (20 mm dia) from bottom.

- Honeycombing and spalling of concrete with the reinforcement exposed was also noticed in the soffit slab, end diaphragm wall and the tapering bottom slab in a length of about 1.8-2.0 m.

- Schmidt rebound hammer test (refer figure 4), though not carried out on old concrete for assessment of concrete strength, yet with no other alternative available, it was used to roughly assess the in-situ concrete strength of the end diaphragm walls and the webs meet the requisite compressive strength criteria of $40 \mathrm{MPa}$ except few locations where concrete was damaged or localized repair had been carried out. The quality of concrete falls in the category of 'Good' as obtained from the ultrasonic pulse velocity test (refer figure 5).

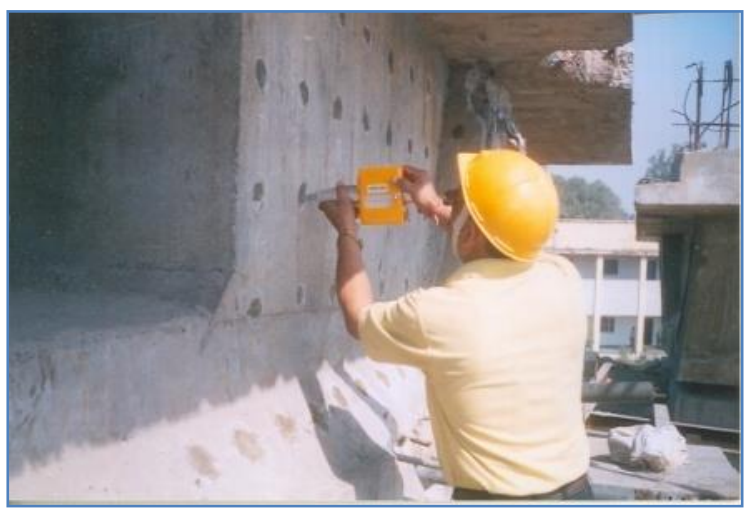

a) On Diaphragm Wall

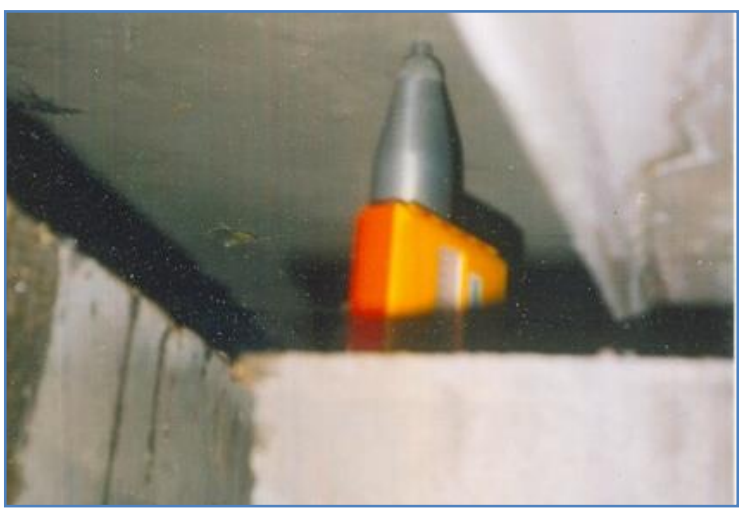

b) On Soffit of Bottom Slab

Figure 4. Schmidt Hammer testing

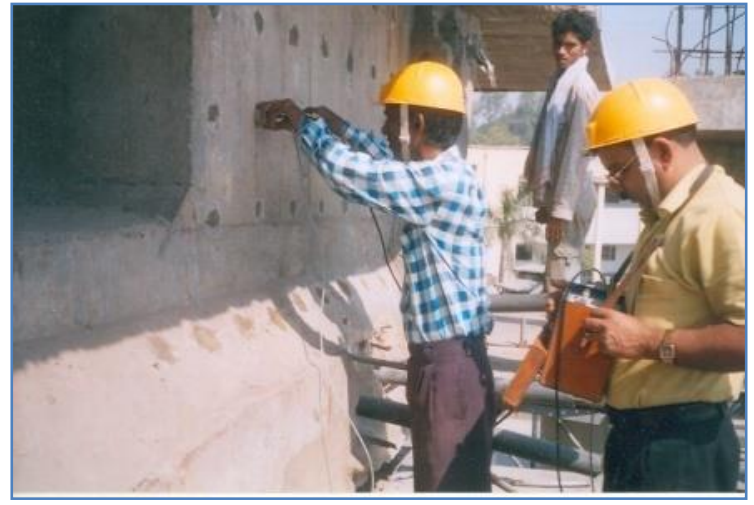

a) On Diaphragm Wall

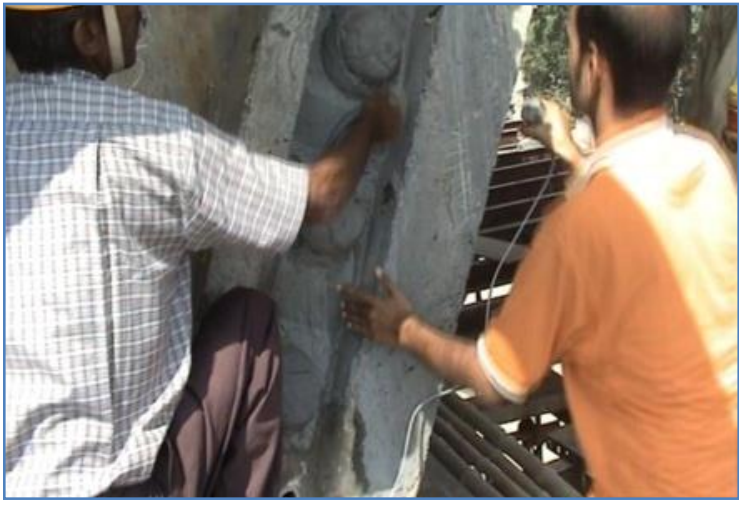

b) On Extended Web Portions

Figure 5. Ultrasonic Pulse Velocity Testing 
From the examination of honeycombing by Boroscope (refer figure 6), it was observed that there was honeycombing along the length of the ducts in the unstressed anchorages on both the ends. The extent of honeycombing in the anchorage zone, especially on the Faizabad end was found to a length of about $0.5 \mathrm{~m}$. This honeycombing in this zone was the main reason for failure of the anchorages during the prestressing. Therefore, the unstressed anchorages were in need of immediate repair before prestressing.

Carbonation depth at the randomly selected test locations in End Diaphragm wall was found to be around $2 \mathrm{~mm}$ only. Spacing of the reinforcement at the randomly selected test locations of End Diaphragm wall was found to be in accordance with the design drawings.

Thus, from the above field observations and investigation, following was inferred:

- The in-situ compressive strength of concrete in the investigated region meets the requisite strength and the overall quality of concrete falls in the category of 'Good'.

- The anchorage zone of unstressed anchorages exhibited honeycombing and needed repair before prestressing.

- The soffit slab in the bearing region, where a large honeycombing and spalling of concrete was observed, also demanded repair.
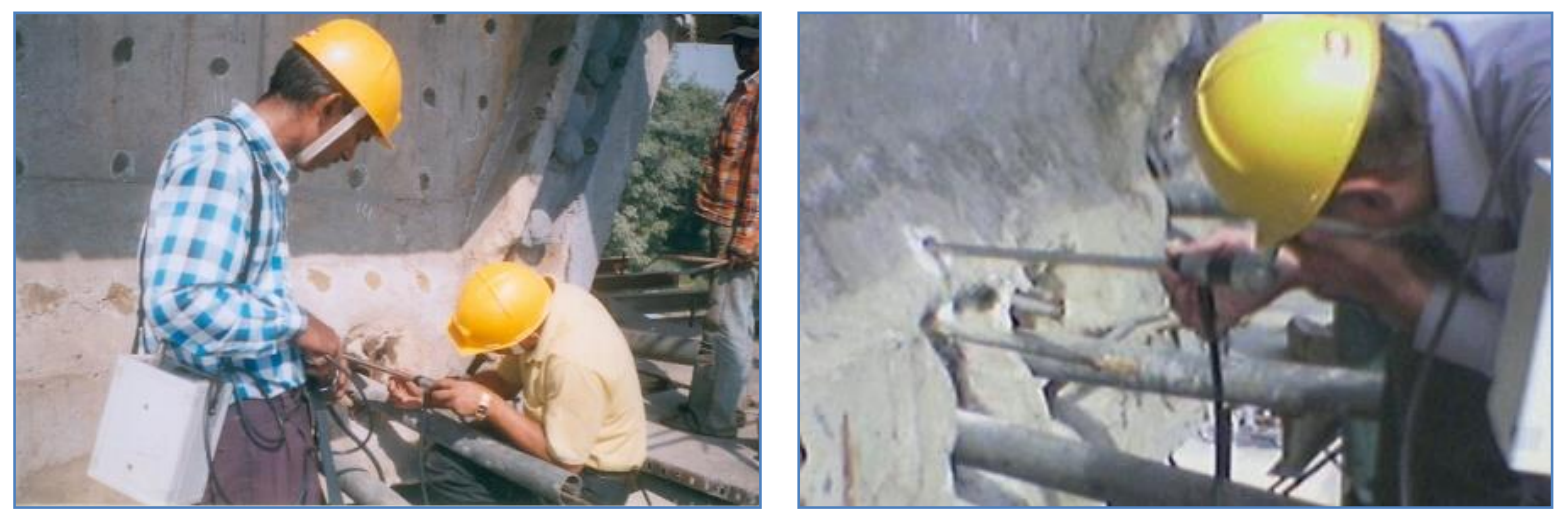

Figure 6. Examination of honeycombing through Boroscope around Anchorage zone

\section{STRENGTHENING MEASURES}

Following strengthening measures were recommended for the repair of spalled and honeycombed concrete in the anchorage zone as well as in the soffit slab:

\section{Repair of Spalled Concrete}

For overhead repairs (in the vicinity of bearings), shotcrete is ideal which uses almost half as much water as compared to conventional concrete. This low water-cement ratio and high density makes the shotcrete a high strength repair material.

Before carrying out shotcrete, loose concrete was removed. Wherever reinforcing bars were exposed, the concrete was removed from around the bars, to allow the repair mortar to properly bond to steel and 
concrete. All the loose material, both concrete chips and rust film, was removed and the surface was cleaned by a jet of compressed air.

The corroded reinforcing steel was sand blasted to get rid of the rust. In case of loss of corroded rebar diameter in the range of $25-30 \%$ of the original dia, it was supplemented by additional reinforcing bars as per site requirements. The exposed bars were treated with an anticorrosive coating layer such as epoxy coating. A second coat, if needed, was provided to achieve a uniform and continuous film.

A good bond between old and new concrete was obtained by applying an epoxy bonding coat just before applying the shotcrete. A shotcrete in the ratio of 1: 2: 2 (cement: fine aggregate: coarse aggregate retained $4.75 \mathrm{~mm}$ size) with compressive strength not less than $40 \mathrm{MPa}$, was then applied with suitable pressure. The hardened surface of the freshly placed shotcrete layer was broomed or scarified and dampened before applying the next layer. Immediately after shotcreting, the repair surface was screeded for a flashcoat finish. The completed surfaces were cured. Wherever, the depth of spalled concrete was more than $75 \mathrm{~mm}$, a wire mesh was fixed before shotcreting.

\section{Repair of Honeycombed Areas}

In the honeycombed areas, epoxy injection grouting was recommended. Epoxy of low viscosity, nonshrinkable, high early strength and ultimate strength to not be less than the in-situ concrete strength, 40 MPa was used.

\section{Prestressing of Remaining Five Tendons}

After the completion of the repair of spalled and honeycombed concrete, the remaining five prestressing tendons were recommended to be prestressed. Before inserting the prestressing tendons in the ducts for prestressing, these ducts were cleaned by cleaning agents to avoid choking.

\section{POST REHABILITATION FIELD INVESTIGATIONS}

The spalled concrete in the anchorage zone and vicinity of bearing area, soffit slab and both the end diaphragms of span P2-P3 was repaired using the shotcrete technique. Epoxy injection grouting was carried out in the honeycombed areas by fixing nozzles around anchorage zones, diaphragm walls, inclined webs, soffit slabs of diaphragm walls and the portions underneath the soffit slab. Figure 7 shows the typical views of the span after these repairs.

The in-situ surface strength (representative) of the shotcreted region was determined by using Schmidt rebound hammer test after about one week of its application. From this test, average compressive strength of concrete was found to be 16.90 and $26.77 \mathrm{MPa}$ at the bottom of soffit slabs at Sitapur and Faizabad end respectively which was lower than the target strength of $40 \mathrm{MPa}$ at 28 days. After 28 days, compressive strength was tested by UP PWD and was found to be more than the target strength. No signs of honeycombing were traced in boroscope study near the anchorage zones.

After being satisfied with the results of non-destructive testing, remaining five prestressing tendons (four in soffit slab and one in web) were stressed successfully in December 2007 to the requisite level of stressing without any punching of concrete in the anchorage region. During prestressing of the remaining five prestressing cables, mid-span deflections of the span were also monitored (figure 8 ) to observe post repair behaviour of the bridge. Upward deflections were noticed with the stressing of the prestressing cables, indicating the satisfactory effectiveness of the repairs. After the removal of shuttering plates, observed spalled and honeycombed concrete was repaired using the methodology given earlier. 

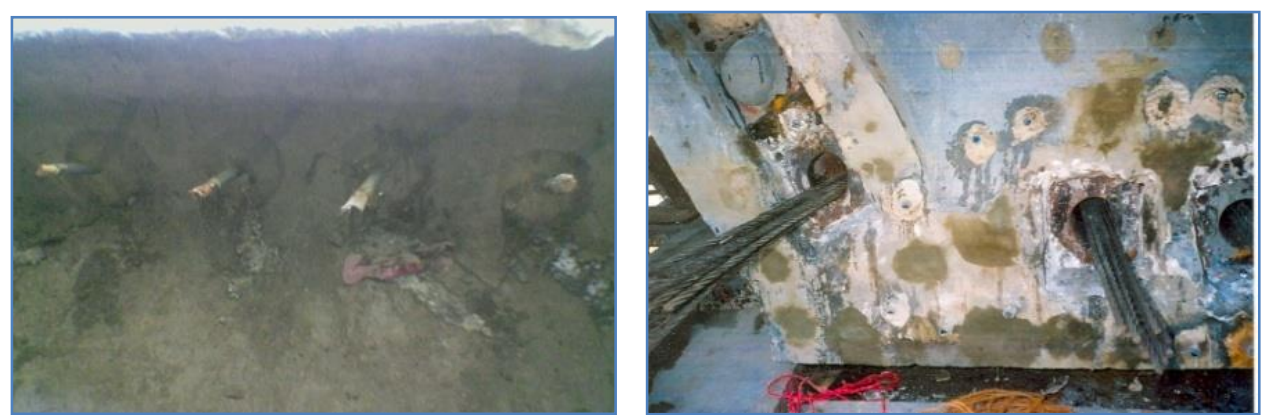

Figure 7. View of the Span after Repairs
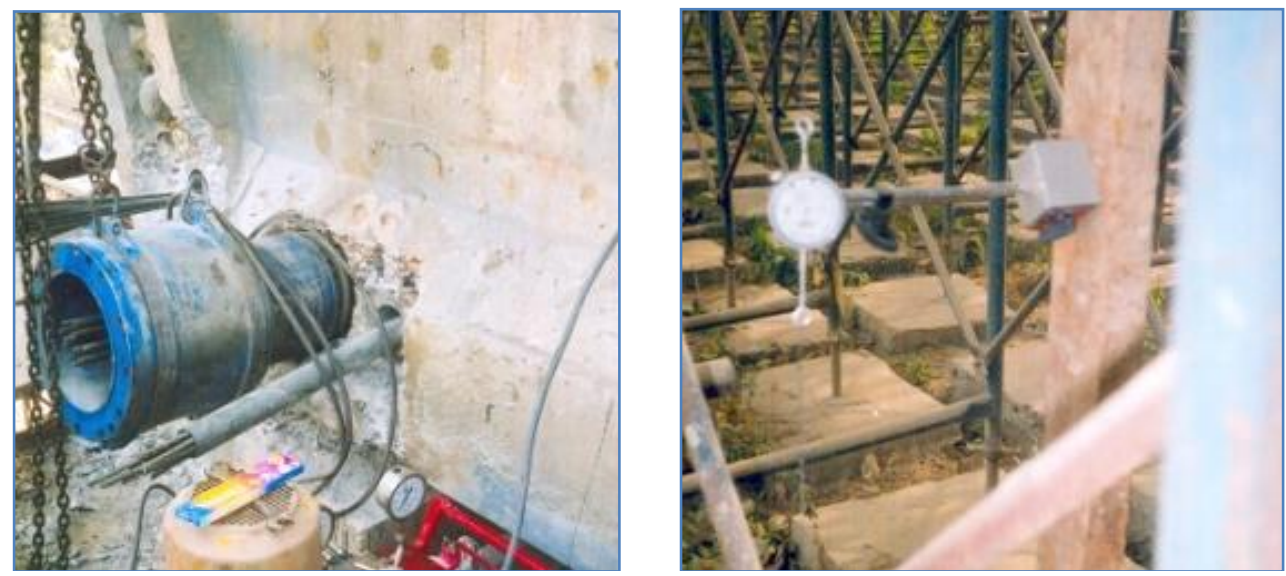

Figure 8. Deflection Measurements of the Span during Prestressing of Tendons

\section{LOAD TESTING}

Prior to commence the load testing of the span of the bridge in February 2009, theoretical studies and field investigations were carried out.

\section{Theoretical Study}

The bridge span was modelled and analysed using software STAAD.pro. In addition to the self-weight of the bridge and live loads on the bridge, the weight of $25 \mathrm{~mm}$ thick remaining Bituminous Concrete (BC) and footpath live load was also considered in computing the maximum Bending Moments. The maximum Bending Moment values are given in Table-1.

Table 1. Details of Loads applied over the Test span

\begin{tabular}{|c|c|c|c|c|c|c|}
\hline \multirow{2}{*}{$\begin{array}{l}\text { Sl. } \\
\text { No. }\end{array}$} & \multirow{2}{*}{$\begin{array}{l}\text { Details of Tested } \\
\text { Span }\end{array}$} & \multicolumn{4}{|c|}{ Max. Bending Moments (T.m) } & \multirow[b]{2}{*}{$\begin{array}{l}\text { Max. BM due to } \\
\text { applied loads } \\
\text { using } 12 \text { trucks } \\
\text { of } 15 \mathrm{~T} \mathrm{GVW} \\
\text { (T.m) }\end{array}$} \\
\hline & & $\begin{array}{l}\text { Live load as } \\
\text { per IRC } \\
\text { loading } \\
\text { including } \\
\text { Impact factor }\end{array}$ & $\begin{array}{l}\text { Live load } \\
\text { on } \\
\text { footpath }\end{array}$ & $\begin{array}{l}\text { Remaining wt. } \\
\text { of } 25 \mathrm{~mm} \text { thick } \\
\text { wearing coarse }\end{array}$ & $\begin{array}{c}\text { Total } \\
\text { BM } \\
(3+4+5)\end{array}$ & \\
\hline$(1)$ & $(2)$ & (3) & (4) & (5) & (6) & (7) \\
\hline 1 & $\begin{array}{l}\text { Grade separator of } \\
\text { span } 35.5 \mathrm{~m} \text { on outer }\end{array}$ & 805 & 59 & 85 & 949 & 957 \\
\hline
\end{tabular}


Ideally the load testing should have been done through platform loading as specified in SP-51-1999. However, due to limited available time for load testing, the loading has been applied through twelve numbers of standard configuration trucks (TATA 1608 model with $4.2 \mathrm{~m} \mathrm{c} / \mathrm{c}$ axle spacing). The Gross Vehicle Weight 9GVW) of each truck was $15 \mathrm{~T}$. The total loading has been applied in five stages, placed in ascending order viz., 25\% of loading represented by 3 nos. of trucks; $50 \%$ of loading represented by 6 nos. of trucks; $70 \%$ of loading represented by 8 nos. of trucks; $90 \%$, of loading represented by 10 nos. of trucks and finally $100 \%$ of loading represented by 12 nos. of trucks. These trucks were kept stationery over the span for next 24 hours. The unloading operation has been done in the similar pattern as of loading operation in descending order, i.e., 90\%, 70\%, 50\%, 25\% and 0\%. Figure 9 shows the typical views of the placement of the trucks over the span during load testing.

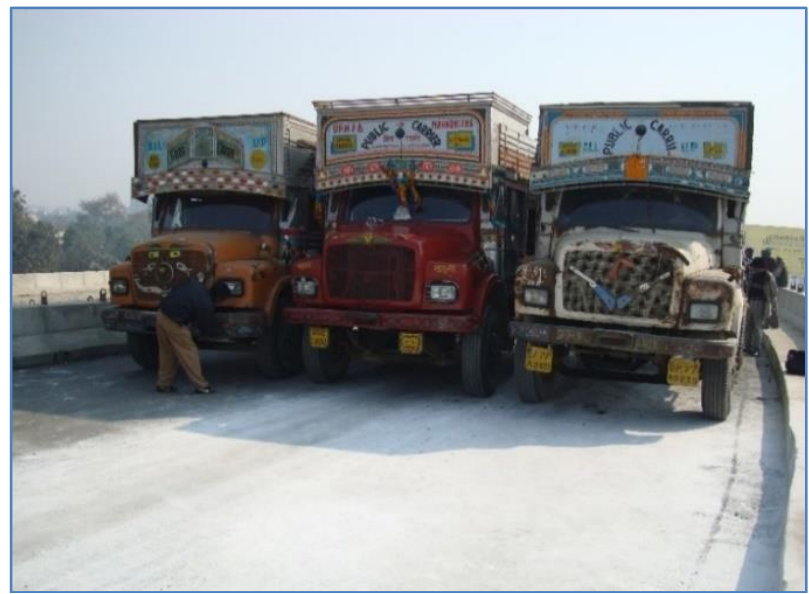

3 trucks (25\% load)

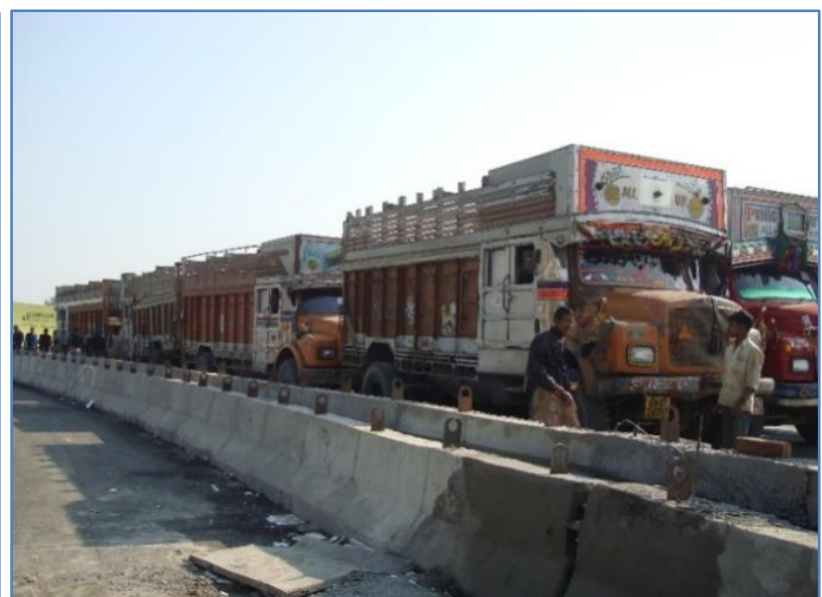

12 trucks $(100 \%$ load $)$

Figure 9. Placement of trucks over the span

\section{Field Investigations}

Before carrying out any testing of a concrete structure, condition survey by visual inspection of the structure is a must. Material deterioration is often indicated by surface cracking and spalling of concrete. The span was thoroughly inspected for any possible distress. Though, the structure had already undergone considerable repairs due to honeycombing, repairs on construction cold joints and on earlier distressed portions, it was very difficult to distinguish between crack and a repaired surface. As, the deck slab top surface covered with $40 \mathrm{~mm}$ thick asphalt layer, so it was not possible to examine each and every surface of the structure. Therefore, exposed area from inside the box girder was inspected for any major distress. The span P2-P3 (outer carriageway) was recently repaired and therefore was found in good condition.

The deflection parameter is the basic parameters in any load testing and acceptability of the structure depends upon behaviour of the bridge superstructure at working load in elastic range. The deflections at mid-span and quarter-spans were monitored along the length and width of box girder (near edges of cantilevers and centre of box). Thus, total nine numbers of points were monitored in each span using dial gauges with $0.001 \mathrm{~mm}$ least count. Suspended wire method (figure 10) was used for deflection measurement.

In addition to monitoring of the deflection of the span, displacement/rotation of bearings were also monitored through dial gauges. A special attachment was fabricated to record the above measurements as shown in figure 11. 


\section{Results and observations}

Prior to commencement of load testing, the deflections of the span were recorded for 24 hours without any load over the span, due to change in atmospheric temperature. During load testing, the loads (truck load) were placed in an eccentric fashion (400 $\mathrm{mm}$ from the edge of footpath) so as to produce maximum bending moment for the desired configuration of live loads. Deflection measurements with the help of dial gages were recorded for each stage of loading. After final stage $(100 \%)$ of loading, deflections were monitored for next 24 hours. After 24 hours of full stage loading, the removal of load was initiated and carried out in same sequence and deflections were observed for their recovery at each stage. After the complete removal of all loads from the deck, deflections were again recorded on hourly basis for next 24 hours. Deflections of the span after applying temperature corrections are given in Table-2. It is observed that the net deflection remained within the theoretical values and much lower than the maximum allowable deflection, i.e., L/1500 as per IRC: SP-37. The percentage recovery of deflection of the span was also within the acceptance criteria, i.e., more than $85 \%$ as per IRC: SP-51. The displacement/rotation of bearings was also much below the allowable values under the static load test.
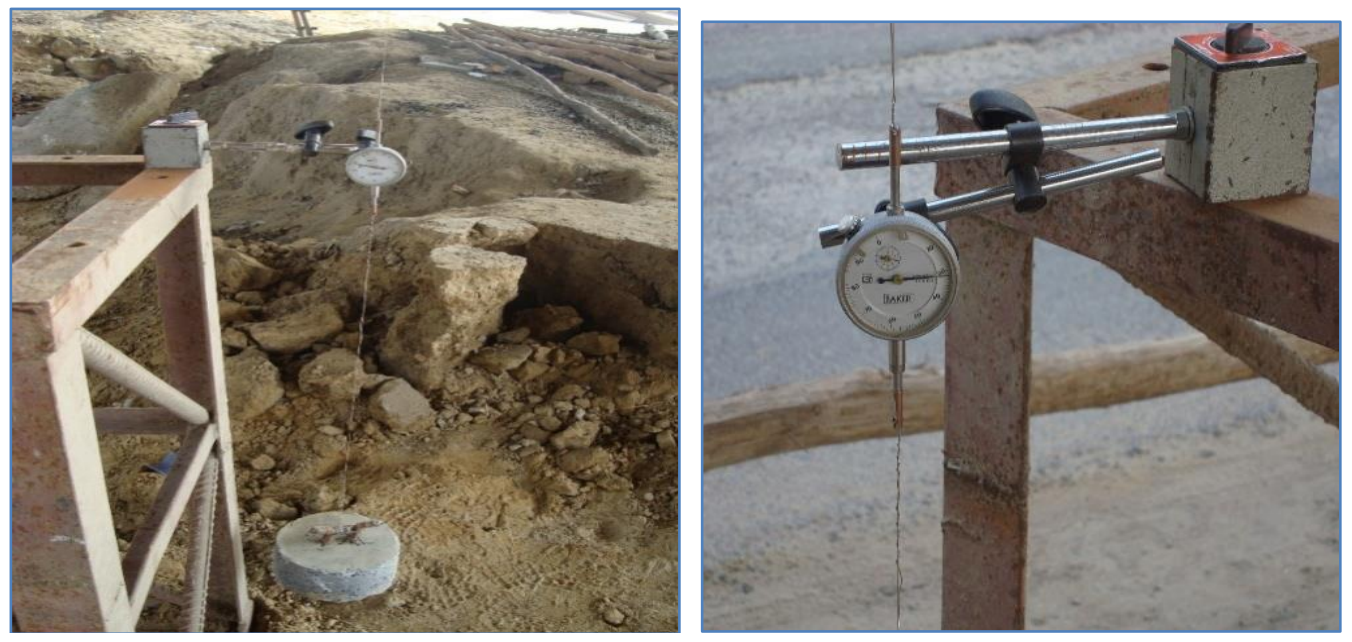
Figure 10. Typical arrangements for deflection measurement showing Dial gauge with
suspended wire
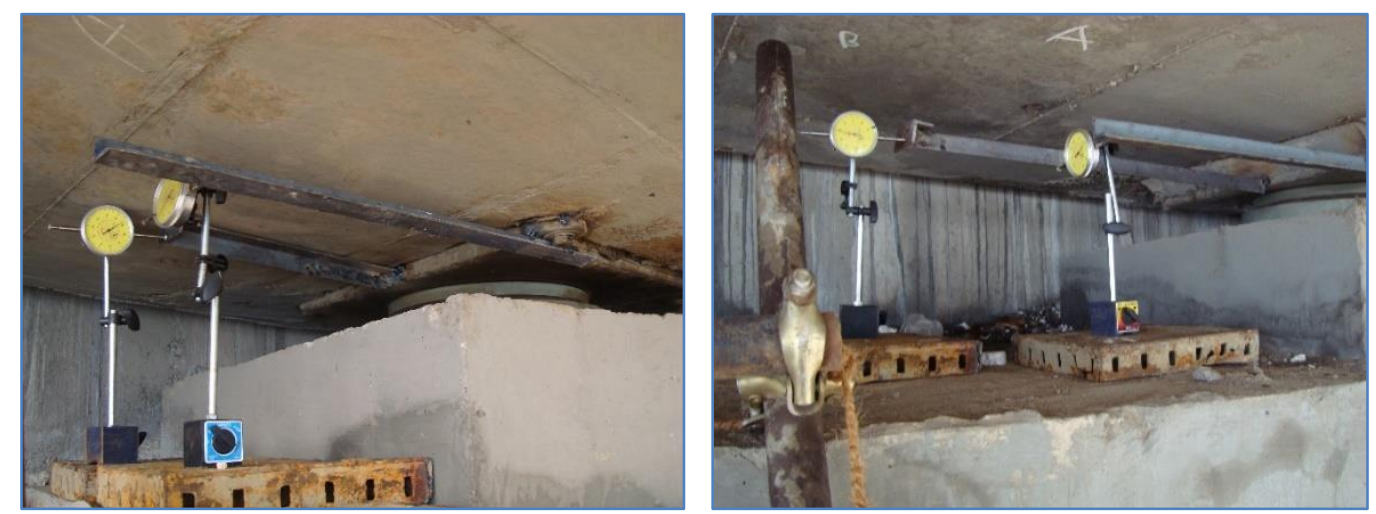

Figure 11. Placement of dial gauges for longitudinal and transverse movement of Free Type bearing 
Glass strips were pasted before the load test at number of places across the cracks and on critical zones. During and after load testing, the structure did not show any spalling or cracks either in shear zones or in flexure zone. All the glass strips remained intact with the surface.

Table 2. Deflection after Temperature Correction of Span P2-P3

\begin{tabular}{|c|c|c|c|c|c|c|c|}
\hline \multirow{3}{*}{$\begin{array}{l}\text { Sr. } \\
\text { No. }\end{array}$} & \multirow{3}{*}{$\begin{array}{l}\text { Deflection } \\
\text { Measurement } \\
\text { Locations }\end{array}$} & \multicolumn{5}{|c|}{ Deflection (mm) } & \multirow{3}{*}{$\begin{array}{l}\text { \%age of } \\
\text { Recovery } \\
\text { ((R3- } \\
\text { R5)/ (R3- } \\
\text { R1)) } \\
* 100\end{array}$} \\
\hline & & $\begin{array}{l}\text { Initial } \\
\text { Reading }\end{array}$ & $\begin{array}{l}\text { Immediate } \\
\text { after } \\
\text { Placement } \\
\text { of } 100 \% \\
\text { Load } \\
\end{array}$ & $\begin{array}{l}\text { Placement } \\
\text { of } 100 \% \\
\text { Load after } \\
24 \mathrm{hrs}\end{array}$ & \multirow[t]{2}{*}{$\begin{array}{l}\text { Immediate } \\
\text { After } \\
\text { unloading } \\
\text { of } 100 \% \\
\text { Load } \\
\text { R4 }\end{array}$} & \multirow[t]{2}{*}{$\begin{array}{l}\text { After } 24 \\
\text { hrs of } \\
\text { Unloading } \\
\text { of } 100 \% \\
\text { Load } \\
\text { R5 }\end{array}$} & \\
\hline & & $\mathrm{R} 1$ & $\mathrm{R} 2$ & R3 & & & \\
\hline 1 & L/4 - Inner & 0 & -4.595 & -4.925 & -0.205 & -0.115 & 97.66 \\
\hline 2 & L /4 - Centre & 0 & -5.165 & -5.775 & 0.375 & -0.285 & 95.06 \\
\hline 3 & L /4 - Outer & 0 & -7.9 & -9.05 & -1.52 & -0.42 & 95.35 \\
\hline 4 & $\mathrm{~L} / 2$ - Inner & 0 & -6.62 & -7.22 & 0.22 & -0.22 & 96.95 \\
\hline 5 & L / 2 - Centre & 0 & -7.215 & -8.515 & 0.595 & -0.395 & 95.36 \\
\hline 6 & $\mathrm{~L} / 2-$ Outer & 0 & -9.615 & -10.475 & 0.085 & -0.335 & 96.80 \\
\hline 7 & 3L /4 - Inner & 0 & -4.905 & -4.885 & 0.025 & -0.185 & 96.21 \\
\hline 8 & 3L /4-Centre & 0 & -4.89 & -5.63 & 0.82 & -0.23 & 95.91 \\
\hline 9 & 3L /4 - Outer & 0 & -7.515 & -7.525 & -0.435 & -0.126 & 98.32 \\
\hline
\end{tabular}

\section{CONCLUSION}

Before carrying out repair and rehabilitation of any distressed structure, it is essential that proper distressdiagnosis shall be done to find out the root cause(s). After which, it is not very difficult to carryout successful repair and rehabilitation of the structure. This was shown with a case study of prestressed concrete single-cell box-girder bridge.

\section{ACKNOWLEDGEMENTS}

Authors are thankful to Director, CSIR-CRRI, New Delhi, India for according his approval to publish this paper. Authors are grateful to UP Public Works Department for their financial support and providing needful help and active support during the field studies of the bridge. Thanks are also due to all those CSIR-CRRI officials who directly or indirectly helped us in this work.

\section{REFERENCES}

"Assessment of quality of concrete in the vicinity of end diaphragm walls of box girder in span P2-P3 (outer carriageway) of existing 2-lane grade separator on NH 24-A Bypass, Lucknow city", Report No. CRRI/QSP/BAS/CNP-1468, CSIR-CRRI, New Delhi, October 2007.

"Assessment of quality of concrete in the vicinity of end diaphragm walls of box girder in span P2-P3 (outer carriageway) of existing 2-lane grade separator on NH 24-A Bypass, Lucknow city", Report No. CRRI/QSP/BAS/CNP-1468, CSIR-CRRI, New Delhi, January 2008.

"Performance Evaluation of the Four Spans of a Grade Separator and Two Spans of a ROB Connecting National Highways 24 and 28 at Lucknow Through Load Testing”, Report No. CRRI/BAS/CNP- 
1540, CRRI, New Delhi, March 2009.

BS:1881 (Part-203), 1970. "British standard code of recommendations for measurement of ultrasonic pulses in concrete", British Standard Institute, London.

BS:1881(Part-120), 1970. "British standard code of methods for determination of compressive strength of Concrete", British Standard Institute, London.

Galan. A. (1990). “Combined ultrasonic methods of concrete testing”, Elsevier, Amsterdam.

IRC:76, 1980 "Tentative guidelines for structural strength evaluation of rigid airfield pavements", Indian Roads Congress, New Delhi.

IRC:SP-37-1991. "Guidelines for Load Carrying Capacity of Bridges", Indian Roads Congress, New Delhi.

IRC:18-2000. "Design criteria for prestressed concrete road bridges (Post-Tensioned concrete)", The Indian Roads Congress, New Delhi.

IRC:6-2000. "Standard Specifications and Code of Practice for Road Bridges, Section: II Loads and Stresses", The Indian Roads Congress, New Delhi.

IRC:SP:51-1999. “Guidelines for Load Testing of Bridges”, Indian Roads Congress, New Delhi.

IS:13311, Part-1, 1992. "Non-destructive testing of concrete - Methods of tests - Ultrasonic pulse velocity", Bureau of Indian Standards, New Delhi.

IS:13311, Part-2, 1992. "Non-destructive testing of concrete - Methods of tests - Rebound hammer", Bureau of Indian Standards, New Delhi.

IS:456-2000. "Code of practice for plain and reinforced concrete", Bureau of Indian Standards, New Delhi.

IS:516-1956. "Indian standard code of methods of tests for strength of concrete", Bureau of Indian Standards, New Delhi. IS 1343-1980, "Indian Standard code of practice for prestressed concrete", Bureau of Indian Standards, New Delhi. 